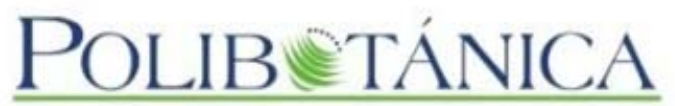

\section{Polibotánica}

ISSN electrónico: 2395-9525

polibotanica@gmail.com

Instituto Politécnico Nacional

México

http:www.polibotanica.mx

\title{
GERMINATION RESPONSE OF TWO SHRUB SPECIES UNDER CONTROLLED CONDITIONS AND TO SECONDARY VEGETATION REMOVAL (WEEDING) IN THE MAGDALENA RIVER BASIN, MEXICO
}

\section{RESPUESTA GERMINATIVA DE DOS ESPECIES DE ARBUSTOS BAJO CONDICIONES CONTROLADAS Y A LA REMOCIÓN DE LA VEGETACIÓN SECUNDARIA (CHAPONEO) EN LA CUENCA DEL RÍO MAGDALENA, MÉXICO}

Martínez-Orea, Y.; A. Orozco-Segovia, L. Bonilla-Valencia, J.A. Zavala-Hurtado, E. VegaPeña, and S. Castillo-Argüero.

GERMINATION RESPONSE OF TWO SHRUB SPECIES UNDER CONTROLLED CONDITIONS AND TO SECONDARY VEGETATION REMOVAL (WEEDING) IN THE MAGDALENA RIVER BASIN, MEXICO.

RESPUESTA GERMINATIVA DE DOS ESPECIES DE ARBUSTOS BAJO CONDICIONES CONTROLADAS Y A LA REMOCIÓN DE LA VEGETACIÓN SECUNDARIA (CHAPONEO) EN LA CUENCA DEL RÍO MAGDALENA, MÉXICO.

POLIBETANICA Instituto Politécnico Nacional
Núm. 48: 1-16 México. Julio 2019

DOI: $10.18387 /$ polibotanica.48.11 (c) (5) 8 Este es un artículo de acceso abierto bajo la licencia Creative Commons 4.0 


\section{GERMINATION RESPONSE OF TWO SHRUB SPECIES UNDER CONTROLLED CONDITIONS AND TO SECONDARY VEGETATION REMOVAL (WEEDING) IN THE MAGDALENA RIVER BASIN, MEXICO}

\section{RESPUESTA GERMINATIVA DE DOS ESPECIES DE ARBUSTOS BAJO CONDICIONES CONTROLADAS Y A LA REMOCIÓN DE LA VEGETACIÓNSECUNDARIA (CHAPONEO) EN LA CUENCA DEL RÍO MAGDALENA, MÉXICO}

Martínez-Orea, Y., A. OrozcoSegovia, L. Bonilla-Valencia, J.A. Zavala-Hurtado, E. VegaPeña, and S. Castillo-Argüiero

GERMINATION RESPONSE OF TWO SHRUB SPECIES UNDER CONTROLLED

CONDITIONS AND TO

SECONDARY VEGETATION

REMOVAL (WEEDING) IN

THE MAGDALENA RIVER BASIN, MEXICO

RESPUESTA

GERMINATIVA DE DOS

ESPECIES DE ARBUSTOS

BAJO CONDICIONES

CONTROLADAS Y A LA

REMOCIÓN DE LA

VEGETACIÓN

SECUNDARIA (CHAPONEO)

EN LA CUENCA DEL RÍO

MAGDALENA, MÉXICO

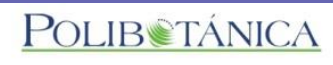

Instituto Politécnico Nacional

Núm. 48: 135-150. Julio 2019

DOI:

10.18387/polibotanica.48.11

\begin{abstract}
Y. Martínez-Orea
Departamento de Ecología y Recursos Naturales,
\end{abstract} Facultad de Ciencias, Universidad Nacional Autónoma de México.

A. Orozco-Segovia

Departamento de Ecología Funcional, Instituto de Ecología, Universidad Nacional Autónoma de México.

L. Bonilla-Valencia

Departamento de Ecología y Recursos Naturales, Facultad de Ciencias, Universidad Nacional Autónoma de México.

J.A. Zavala-Hurtado

Departamento de Biología, Universidad Autónoma Metropolitana, Iztapalapa.

E. Vega-Peña

Instituto de Investigaciones en Ecosistemas y Sustentabilidad IIES, Universidad Nacional Autónoma de México Morelia, Michoacán

S. Castillo-Argüero / silcas@ ciencias.unam.mx Departamento de Ecología y Recursos Naturales, Facultad de Ciencias, Universidad Nacional Autónoma de México.

ABSTRACT: Temperate forests are heterogeneous because of their variable topography which causes that environmental variables are different between slopes. The availability of microsites for seed germination is crucial for natural regeneration. Secondary vegetation removal (weeding) is practiced in Central Mexico's forests as part of silvicultural practices. To evaluate its effects on germination we performed an experiment with microsite types of different orientations South/North $(\mathrm{S} / \mathrm{N})$ and with/without secondary vegetation (Undisturbed/Perturbed) (US, UN, PS, PN). Light (global site factor $[\mathrm{GSF}]$ and red/far-red [R/FR] ratio), soil temperature, moisture, $\mathrm{pH}$, nitrogen $(\mathrm{Ni})$ and germination of two shrub species were measured at 24 microsites. Results were analyzed with generalized linear models, variation coefficients and Kruskal-Wallis tests. Light values exhibited higher values at US because South-facing sites receive higher solar radiation than North-facing ones and because canopy gaps were larger. R/FR ratios were significantly different between $\mathrm{U}$ and $\mathrm{P}$, and $\mathrm{N}$ and $\mathrm{S}$ microsites; the highest values were registered at PS microsites because of their orientation and because of the absence of understory vegetation, which filters light. Soil temperature was the highest at PS and PN. Soil moisture was the highest at UN and US because secondary vegetation avoids soil moisture loss. Germination percentages of both species were the highest at US because secondary 
species have high light and soil moisture requirements. $\mathrm{pH}$, soil moisture and GSF had a significant effect on Ageratina glabrata, while $\mathrm{pH}, \mathrm{Ni}$, soil temperature and moisture were significant for Senecio angulifolius. This practice can have negative effects on shrubs species germination. We do not recommend weeding, because it can have negative effects on shrub species germination.

Key words: Microsite; light and moisture; forest management; slope orientation.

RESUMEN: Los bosques templados son heterogéneos por su topografía variable lo que causa que las variables ambientales sean diferentes entre laderas. La disponibilidad de micrositios para la germinación es crucial para la regeneración natural. La remoción de vegetación secundaria (chaponeo, deshierbe) se practica en bosques del centro de México como parte de las prácticas silvícolas. Para evaluar sus efectos en la germinación establecimos micrositios de diferente orientación (Sur/Norte), con/sin vegetación secundaria (Sin Disturbio U/Perturbado P) (US, UN, PS, PN). La luz (factor de sitio global [GSF], tasa de luz rojo/rojo lejano), temperatura, humedad, pH, Nitrógeno (Ni) del suelo y germinación de dos arbustos fueron medidos en 24 micrositios. Se utilizaron modelos lineales generalizados, coeficientes de variación, pruebas de Kruskal-Wallis para el análisis. La luz fue mayor en US porque los sitios orientados al Sur reciben mayor radiación solar que aquellos al Norte y porque los claros del dosel fueron mayores. R/FR varió significativamente entre micrositios $\mathrm{U}$ y $\mathrm{P}$, y entre $\mathrm{N}$ y $\mathrm{S}$; los mayores valores se registraron en PS por su orientación y ausencia de vegetación secundaria, que filtra la luz. La temperatura fue mayor en PS y PN. La humedad fue mayor en UN y US porque la vegetación secundaria evita su pérdida. La germinación de ambas especies fue mayor en US porque estas especies tienen requerimientos altos de luz y humedad del suelo. El GSF, $\mathrm{pH}$, y humedad tuvieron un efecto significativo para Ageratina glabrata. La temperatura, humedad, pH y Ni lo tuvieron para Senecio angulifolius. No recomendamos el chaponeo porque puede tener efectos negativos en la germinación de semillas de arbustos.

Palabras clave: Micrositio; luz y humedad; manejo forestal; orientación de la ladera.

\section{INTRODUCTION}

Fir forests are very heterogeneous (Canham et al., 1990), one reason is that they are usually located in mountainous landscapes. For example, south-facing slopes are warmer in the northern hemisphere (Stuart et al., 1988), because of the higher incidence of solar radiation than in north-facing slopes, which makes microsites facing south warmer and less humid (MéndezToribio et al., 2016). According to Méndez-Toribio et al. (2016), information on how this topographic asymmetry affects microclimate has been examined for temperate forests, but it has not been studied in terms of germination of secondary species. Secondary species such as shrubs have been recognized as very important in ecological succession because they contribute to maintaining soil moisture (Chaneton et al., 2010) and serve as nurse species for protecting conifer seedlings (Castro et al., 2002; Rodríguez-Trejo, 2006). Germination and establishment of secondary species are crucial for forest regeneration and will respond to environmental variables, such as the light that reaches the forest floor through canopy gaps, soil temperature, moisture (Matlack, 1993) as well as the structure and texture of forest floor that often represents an obstacle for seeds for reaching the soil (Benvenuti and Mazzoncini, 2019). Although secondary species have been reported as abundant or common under some perturbation regimes (Calderón and Rzedowski, 2005); the characterization of safe microsites for their germination might be important for conservation plans (Evans and Young, 1984; Martínez-Orea et al., 2019). Not only slope orientation but also some disturbances can influence microsites causing differences in moisture, temperature, and light compared to conserved sites (Linding and Zedler, 2002; Martínez-Orea et al., 2019). For example, Chen et al. (1999) found differences in air temperature of up to $6{ }^{\circ} \mathrm{C}$ between conserved sites and forest edges in a Pseudotsuga menziesii forest in North America (Washington). 
Seed germination of angiosperms occurs under different light regimes; part of the response to these regimes depends on phytochrome A, which absorbs light of different wavelengths according to its configuration and to light in microsites, and this interaction will affect germination (Orozco-Segovia and Sánchez-Coronado, 2013). Anthropogenic disturbances, in particular some forest management practices (Fowler, 1988), such as control and suppression of understory vegetation, might affect the degree of suitability of microsites for germination (Martínez-Orea et al., 2019). Secondary vegetation control (weeding) is a silvicultural practice aimed to reduce or minimize competition between shrubs or grasses with conifer seedlings, although it has been suggested that the presence of some shrubs and herbs in the understory could ameliorate the microsite environment for tree regeneration of some species such as Pinus palustris (Rodríguez-Trejo, 2006). Some secondary species of pine-oak mountainous areas in Mexico have been reported to germinate in high percentages after fire, especially those with a physiological dormancy, as a consequence of being exposed to fire products such as smoke (Zuloaga-Aguilar et al., 2011). According to González et al. (2013) gradual cutting of trees has been related to regeneration in some forests, because soil is prepared for seed germination of several species, but not specifically shrub species. However, weeding as a silvicultural practice has been reported to cause a decrease in the germination of shrubs such as Symphoricarpos microphyllus in fir forests in central Mexico mainly due to low soil moisture contents (Martínez-Orea et al., 2019). Nevertheless, microsite suitability has not been measured for shrub germination by comparing microsites on north and south-facing slopes, with and without secondary vegetation (as part of forest management) in fir forests of Central Mexico. Ageratina glabrata and Senecio angulifolius are important shrub species in fir forests of this region (Ávila-Akerberg, 2002). They belong to the most diverse group of flowering plants in Mexico (Asteraceae) (Villaseñor, 2003) and are associated with montane systems (Cabrera-Rodríguez and Villaseñor, 1987); they have been recognized as crucial in forest regeneration after disturbance (Bonilla-Valencia et al., 2017a).

\section{Objectives}

The objectives of this work are (1) to measure the germination response of two shrub species: Ageratina glabrata and Senecio angulifolius in different microsites that differ according to their location at different slope orientations (South, North, S, N) and under a forest silvicultural practice that consists in eliminating understory vegetation (weeding) (Undisturbed, Perturbed, $\mathrm{U}, \mathrm{P})$ and (2) to measure their germination response to different light qualities in growth chambers, and seed viability over one year of storage.

\section{MATERIAL AND METHODS}

\section{Study area}

The Magdalena River Basin (MRB) is located southwest of the valley of Mexico at an altitude ranging from 2,570 to $3,870 \mathrm{~m}$. This basin is part of the remnant natural vegetation and soil conservation area of Mexico City (Ávila-Akerberg et al., 2018), covering an area of 3,100 ha. It includes three vegetation types: oak forest (2,700-2,900 m a.s.1., 166.8 ha of which $90 \%$ corresponds to tree and $60 \%$ shrub covers); Abies religiosa (Kunth) Schltdl. and Cham. (fir) forest, the greatest in extension in this site $(2,900-3,650 \mathrm{~m}$ a.s.1, 1,071 ha of which $90 \%$ is covered with trees); and pine forest (3,650 m a.s.l., 1018 ha of which $60 \%$ corresponds to tree cover) (Ávila-Akerberg et al., 2018). The MRB is located at $19^{\circ} 13^{\prime} 53^{\prime \prime} / 19^{\circ} 18^{\prime} 12^{\prime \prime} \mathrm{N}$ and $99^{\circ} 14^{\prime} 50^{\prime \prime} / 99^{\circ} 20^{\prime} 30^{\prime \prime} \mathrm{W}$. The fir forest is dense, with its canopy reaching $40 \mathrm{~m}$, and herbaceous and shrub layers are also present, exhibiting a height between 2 and $3 \mathrm{~m}$, with shrub species such as Acaena elongata L., Ageratina glabrata (Kunth) King \& Rob., Senecio angulifolius DC., S. barba-johannis (DC.) H. Rob. and Brettell (Ávila-Akerberg, 2002; Calderón and Rzedowski, 2005). The soil type is humic andosol at most of the forest sites (SantibáñezAndrade et al., 2015). 
The climate is temperate subhumid, with a summer rainy season and winter rains. The mean annual temperature is $14^{\circ} \mathrm{C}$ (minimum $6^{\circ} \mathrm{C}$, maximum $20^{\circ} \mathrm{C}$ ), and the annual precipitation is between 950 and 1,300 mm (Álvarez-Román, 2000; García, 2004). November to January are the coldest period of the year, with temperatures of $6^{\circ} \mathrm{C}$, and the warmest period is from March to September at $18^{\circ} \mathrm{C}$ (Dobler-Morales, 2010).

This fir forest has a structure with herbaceous, shrub and tree layers and it is permanently affected by human disturbances, such as deforestation, farming, cattle raising, tourism and induced fires (Ávila-Akerberg et al., 2018). In addition, as a forest silvicultural practice, the forest's owners eliminate understory vegetation (weeding), an activity that might represent another important anthropogenic disturbance factor. They cut all shrubs and herbs, usually some roots remain, especially of those shrubs that have deep roots or many stems (such as Ribes ciliatum and Senecio barbo_johannis).

\section{Study species}

The studied species were the shrubs Ageratina glabrata (H.B.K.) King \&Rob. and Senecio angulifolius (DC) (Asteraceae); their fruiting is synchronic during the dry season (BonillaValencia et al., 2017b), and they produce anemochorous dry fruits (Martínez-Orea et al., 2014). Both shrubs are among the most abundant shrub species in the studied area (Ávila-Akerberg, 2002), and they colonize successional sites in fir forests in Central Mexico (Calderón and Rzedowski, 2005).

\section{Microsite characterization}

In the Abies religiosa forest of the MRB we selected a directed sampling: we established microsites according to silvicultural practice and slope orientation. Microsites were representative and comparable (because community people had just practiced silvicultural practices there). Twelve microsites $\left(1 \mathrm{~m}^{2}\right)$ were set on south-facing slopes, half of them (six) were undisturbed (US- non weeded), and the other six were perturbed (PS-weeded) due to silvicultural practices (removal of secondary vegetation, weeding). On north-facing slopes, twelve microsites were established, six were undisturbed (UN-non weeded) and other six were perturbed (PN-weeded). This sets up a design of 24 microsites established at an altitude between 2,932 and 3,170 $\mathrm{m}$.

We characterized microsites in terms of environmental variables such as light, soil temperature and moisture, nitrogen $(\mathrm{Ni})$ and $\mathrm{pH}$, since these variables can influence species germination and they can be modified by slope orientation and forest management. Light availability at the microsites was quantified from nine hemispherical photographs at each microsite taken $1 \mathrm{~m}$ above the ground (NIKON D80 equipped with an EX SIGMA 4.5 fisheye lens, 1.28 DC DSM) free of sun glare following Messier and Puttonen (1995) methodology. These photos were analyzed using the Hemiview canopy analysis software (ver. 2.1), which estimates the global site factor (GSF, $\left.\mathrm{MJm}^{-2} \mathrm{yr}^{-1}\right)$. In addition, in order to describe light quality, red/far-red (R/FR) light ratios were registered with a radiometer (Skye Instruments, SKR 100, United Kingdom) at five random spots of each microsite at the soil level. Light data were measured during one day after the sowing of seeds (at all microsites) from 10:00 to 17:00 local time, according to Vázquez-Yanes et al. (1990) methodology. Means of the five measurements of the R/FR ratio were calculated and plotted for different hours during the day. At each microsite, one data logger (easy LogUSB-ONSET) was set to register the soil moisture content and temperature every day, and at each hour during April 2016. The soil $\mathrm{pH}$ and nitrogen contents were analyzed from a mixed sample (200 g) from three soil samples collected in April from each microsite.

\section{Germination tests in microsites}

Mature fruits (achenes, from now on named seeds) of A. glabrata (2 $\pm 0.02 \mathrm{~mm}$ long) and $S$. angulifolius $(3.3 \pm 0.023 \mathrm{~mm}$ long) were collected from 30 individuals per species on March 27,2016 (dispersal season). Five days after collection, three cloth bags $(8 \mathrm{~cm} \times 8 \mathrm{~cm} ; 0.3 \mathrm{~mm} \times$ 
$0.3 \mathrm{~mm}$ mesh) were filled with 50 seeds each (150 seeds/microsite/species), and they were sown randomly at microsites $(2 \mathrm{~cm}$ depth). Three extra bags of 10 seeds were sown at each microsite; one of them was exhumed after one week and the other two after two weeks to check germination, but these seeds were not included in the analysis. Once germination was registered (two weeks after sowing), all bags were exhumed, and the germinated seeds (emerged radicles) were counted.

\section{Tests in growth chambers}

One day after seeds were collected in the field they were sown in growth chambers, for this, six hundred seeds were disinfected in sodium hypochlorite $(1 \%)$ for three minutes. They were subjected to different light qualities (darkness, white, red far, and red light) in Petri dishes in a germination chamber (controlled conditions as experimental design) (Nuaire model I-36LL, EUA) at $22^{\circ} \mathrm{C} / 20^{\circ} \mathrm{C}, 16 / 8$ photoperiod. Dishes were sealed with a plastic film (Egapack, Mexico) to maintain humidity. Three Petri dishes (replicates, of $9 \mathrm{~cm}$ diameter each) with humid absorbent paper (previously sterilized, as a substrate) per light treatment and with 50 seeds each were set in a growth chamber under: (1) white light (WL; photon flux density (PFD) $=33.21 \mu$ moles $\left.\mathrm{m}^{-2} \mathrm{~s}^{-1}, \mathrm{R} / \mathrm{FR}=1.73\right)$; (2), red light $\left(\mathrm{RL} ; \mathrm{PFF}=5.18 \mu\right.$ moles $\mathrm{m}^{-2} \mathrm{~s}^{-1}, \mathrm{R} / \mathrm{FR}=$ 3.39), (3) far-red light (FRL; PFF $=1.2 \mu$ moles $\mathrm{m}^{-2} \mathrm{~s}^{-1}, \mathrm{R} / \mathrm{FR}=0.05$ ), and (4) darkness (D). PFD between 400 and $700 \mathrm{~nm}$ was measured with a quantometer (Apogee, model MQ-200, Apogee Instruments, Inc., Logan, UT, USA), and the R/FR ratio $(\mathrm{R}=640-670$ y $\mathrm{RL}=690-748 \mathrm{~nm})$ was measured with a radiometer SKR-100 (Skye Instruments, Scotland). For the treatment with RL Petri dishes were set inside a red plexiglass box $(3 \mathrm{~mm}$ thick, $48 \times 32 \times 8 \mathrm{~cm}$, Series 2424 Rohm and Hass, Mexico). For the FRL treatment, Petri dishes were set in a red plexiglass box with a cover of blue plexiglass (same dimensions of the red box, Series 2423). For the treatment in darkness, Petri dishes were covered with aluminum foil. All Petri dishes and plexiglass boxes were set in the mentioned germination chamber equipped with fluorescent lamps (OSRAM de 17 watts and $60 \% \mathrm{RH})$. For 30 days, every third day we registered germination under WL, and one month after being sown, we registered germination in the other light treatments.

\section{Viability tests}

The fraction of the seeds that was not used in growth chambers or planted in microsites was subjected to a tetrazolium test in 2016, following the method proposed by Moreno-Martínez (1996), immediately after collection and one year after storage (2017). Storage was carried out in paper bags in boxes kept in dark conditions and a mean temperature of $16^{\circ} \mathrm{C}$ to evaluate seed viability one year later.

\section{Data analysis}

Microsite characterization was performed using the values of the environmental variables: light, soil temperature and moisture, nitrogen $(\mathrm{Ni})$ and $\mathrm{pH}$; microsites were grouped in microsite types for their analysis: US (undisturbed -non weeded-, south oriented), PS (perturbed -weeded, south oriented), UN (undisturbed -non weeded-, north oriented), PN (perturbed -weeded-, north oriented). In order to find differences in microsites according to their values of environmental variables and their significant effect on the study species germination, we carried out a generalized linear model (GLM) (performed with package glm2), where the response variable was the number of germinated/not germinated seeds (Marschner, 2018); the type of distribution applied was binomial (error: binomial, link function: logit) for R software (Crawley, 2012; R Core Team, 2015). Variation coefficient values [VC] were calculated for each microsite type; these values were then compared through a $Z$ test (Zar, 1999) for the R/FR ratios. A KruskalWallis test was performed to determine whether the microsite had an effect on the germination values per species (Stat Soft STATISTICA 8.0 2007). For the germination tests in growth chambers, germination percentages were calculated. These germination percentages were transformed with the arcsin of the square root (Zar, 1999) and were related to time using a sigmoid exponential function: $y=a /\left(1+\left(b^{*} x c\right)\right)$ for an adjustment to the curves with Table Curve 2D 5.01 (AISN, Chicago IL, EUA) software, in order to calculate lag time and germination rate for each species. 


\section{RESUlTs}

\section{Germination responses of shrub species at microsites}

In general, (considering all microsites) Ageratina glabrata exhibited a slightly higher germination percentage $(\overline{\mathrm{X}}=16.32 \pm$ Standard Error $=0.72)$ than Senecio angulifolius $(\overline{\mathrm{X}}=$ $14.26 \pm$ S.E. $=1.09)$. In microsites both species showed the highest germination percentages at US $(19.83 \pm$ S.E. $=0.85,19.11 \pm$ S.E. $=1.4$ respectively, table 1$)$. The Kruskal-Wallis test revealed significant differences due to the effect of the microsite on the germination percentages of A. glabrata $(\mathrm{H}=40.42, \mathrm{p}=0.013)$. In contrast, no effect of the microsite was found for $S$. angulifolius $(\mathrm{H}=28.75, \mathrm{p}=0.18)$. However, the $\mathrm{GLM}$ analysis showed differences in microsite variables such as soil $\mathrm{Ni}, \mathrm{pH}$, temperature, and moisture and FSG for $S$. angulifolius and in $\mathrm{pH}$, soil moisture and FSG for A. glabrata at different microsite types.

\section{Soil pH and nitrogen $(\mathrm{Ni})$}

The microsites with the highest soil $\mathrm{pH}(\overline{\mathrm{X}}=6.06 \pm$ S.E. $=0.1)$ were the US, whereas the PN microsites exhibited the lowest values $(\bar{X}=5.79 \pm$ S.E. $=0.08)$. The highest soil Ni mean values corresponded to PN microsites $(\bar{X}=0.63 \pm$ S.E. $=0.07 \%)$, whereas the lowest values corresponded to UN microsites $(\overline{\mathrm{X}}=0.5 \pm$ S.E. $=0.07 \%)$, (table 1$)$. The effects of $\mathrm{pH}$ and $\mathrm{Ni}$ at $\mathrm{UN}$ microsites and of $\mathrm{pH}$ at $\mathrm{PN}$ microsites were significant for the germination of $S$. angulifolius. For A. glabrata, the effects of $\mathrm{pH}$ at $\mathrm{UN}$ microsites were also significant (table 2).

Table 1. Values (means \pm Standard Error) of environmental variables and germination percentages of Ageratina glabrata and Senecio angulifolius at four microsite types in the Abies religiosa forest in the Magdalena river basin, Mexico City.

\begin{tabular}{ccccccccc}
\hline $\begin{array}{c}\text { Microsite } \\
\text { type }\end{array}$ & pH & Ni & Temp & Moist & GSF & R/FR & $\begin{array}{c}\text { G \% } \\
\text { A.glabrata }\end{array}$ & $\begin{array}{c}\text { G \% } \\
\text { S.angulifolius }\end{array}$ \\
\hline US & $6.06 \pm 0.01$ & $\mathbf{0 . 5 8} \pm \mathbf{0 . 0 2}$ & $\mathbf{1 1 . 4 1} \pm \mathbf{0 . 1 6}$ & $\mathbf{6 6 . 5 1} \pm \mathbf{0 . 1 6}$ & $450 \pm 12$ & $1.72 \pm 0.14$ & $19.83 \pm 0.85$ & $19.11 \pm 1.4$ \\
UN & $\mathbf{5 . 9 2} \pm \mathbf{0 . 0 2}$ & $\mathbf{0 . 5} \pm \mathbf{0 . 0 7}$ & $\mathbf{9 . 9 9} \pm \mathbf{0 . 0 4}$ & $68.07 \pm 0.17$ & $\mathbf{2 3 6} \pm \mathbf{9 . 6}$ & $\mathbf{1 . 2 8} \pm \mathbf{0 . 0 6}$ & $\mathbf{1 5 . 1 1} \pm \mathbf{0 . 5 7}$ & $\mathbf{1 1 . 0 5} \pm \mathbf{0 . 7 7}$ \\
PS & $\mathbf{6 . 0 3} \pm \mathbf{0 . 1 4}$ & $\mathbf{0 . 5 5} \pm \mathbf{0 . 0 2}$ & $12.24 \pm 0.03$ & $\mathbf{5 7 . 5 2} \pm \mathbf{0 . 1 5}$ & $\mathbf{1 3 4} \pm \mathbf{9 . 1}$ & $\mathbf{1 . 3 0} \pm \mathbf{0 . 1 4}$ & $\mathbf{1 6 . 4 3} \pm \mathbf{0 . 6 2}$ & $\mathbf{1 5} \pm \mathbf{0 . 7 8}$ \\
PN & $\mathbf{5 . 7 9} \pm \mathbf{0 . 0 7}$ & $0.63 \pm 0.07$ & $\mathbf{1 1 . 4 6} \pm \mathbf{0 . 1 6}$ & $\mathbf{6 4 . 6 4} \pm \mathbf{0 . 1 6}$ & $\mathbf{1 4 3} \pm \mathbf{4}$ & $\mathbf{0 . 7 2} \pm \mathbf{0 . 0 5}$ & $\mathbf{1 3 . 9 1} \pm \mathbf{0 . 8 5}$ & $\mathbf{1 1 . 9} \pm \mathbf{1 . 4}$ \\
\hline
\end{tabular}

$\mathrm{Ni}$ (soil nitrogen, \%), Temp (soil temperature, ${ }^{\circ} \mathrm{C}$ ), Moist (soil moisture, \%), GSF (global site factor $\mathrm{MJm}^{-2} \mathrm{y}^{-1}$ ), R/FR (red/far red ratio), G\% (germination percentage) at four microsite types: US (undisturbed -non weeded-, south oriented), PS (perturbed -weeded-, south oriented), UN (undisturbed -non weeded-, north oriented), PN (perturbed weeded-, north oriented).

\section{Light in microsites}

For the GSF and the R/FR ratios, the highest values were registered at US microsites $(\bar{X}=450 \pm$ S.E. $=12$ and $\bar{X}=1.72 \pm$ S.E. $=0.14$, respectively, table 1$)$. The effects of the GSF variable at $\mathrm{UN}$ were significant for the germination of A. glabrata (table 2).

At all microsites, the R/FR values varied statistically throughout the day $(\mathrm{H}=26.8, \mathrm{p}<0.0001)$ (fig. 1). The greatest VC value was found at the PS microsites [VC $=1.02]$, whereas for the other microsites, the variations were smaller: $\mathrm{UN}$ [VC $=0.85$ ], US [ $\mathrm{VC}=0.82$ ], $\mathrm{PN}$ [VC $=$ 0.67]. Between microsites statistical differences in the VC values were also found: $\mathrm{UN}$ and $\mathrm{PN}$ $(\mathrm{Z}=2.1>0.73, \mathrm{p}<0.05)$, UN and PS $(\mathrm{Z}=1.3>0.95, \mathrm{p}<0.05$, PS and US $(\mathrm{Z}=2.4>0.95, \mathrm{p}=$ $0.03)$, PS and PN $(Z=1.17>0.48, p<0.05)$, and US and PN $(1.30>0.48, p=0.01)$. The exception was the comparison between the UN and US microsites $(Z=0.85<1.24, p=0.31)$. 
According to the GLM analysis, R/FR ratios at microsites did not show significant effects on the germination of the studied species.

Table 2. Results of the GLM (Generalized linear model) analysis for environmental variables for Ageratina glabrata and Senecio angulifolius at four microsite types in the Abies religiosa forest in the Magdalena river basin, Mexico City.

\begin{tabular}{|c|c|c|c|c|c|c|}
\hline Species & $\begin{array}{c}\text { Microsite } \\
\text { type }\end{array}$ & pH & $\mathbf{N i}$ & Temp & Moist & GSF \\
\hline \multirow[t]{4}{*}{ A. glabrata } & US & & & & & \\
\hline & UN & $-2.63(0.7)^{* *}$ & & & $-2.42(0.01)^{*}$ & $2.7(0.7)^{* *}$ \\
\hline & PS & & & & & \\
\hline & $\mathrm{PN}$ & & & & & \\
\hline \multirow[t]{4}{*}{ S. angulifolius } & US & $-2.14(4.38)^{*}$ & $1.9(4.94), \mathrm{p}=0.05$ & & & \\
\hline & UN & & & $-2.25(0.05)^{*}$ & $3.94(0.018)^{* * *}$ & \\
\hline & PS & & & & & \\
\hline & PN & $-2.4(2.15 \mathrm{e}+00)^{*}$ & & $2.3(1.41 \mathrm{e}+02)^{*}$ & $2.3(1 \mathrm{e}+02)^{*}$ & \\
\hline
\end{tabular}

$\mathrm{Ni}$ (soil nitrogen, \%), Temp (soil temperature, ${ }^{\circ} \mathrm{C}$ ), Moist (soil moisture, \%), GSF (global site factor $\mathrm{MJm}^{-2} \mathrm{y}^{-1}$ ), and for G\% (germination percentage) of Ageratina glabrata and Senecio angulifolius at four microsite types: US (undisturbed -non weeded-, south oriented), PS (perturbed -weeded-, south oriented), UN (undisturbed -non weeded, north oriented), PN (perturbed -weeded-, north oriented). Asterisks indicate significant differences at $\mathrm{p} \leq 0.05\left(^{*}\right)$, $\mathrm{p} \leq 0.005(* *)$. Only values of variables that had a significant effect are shown.

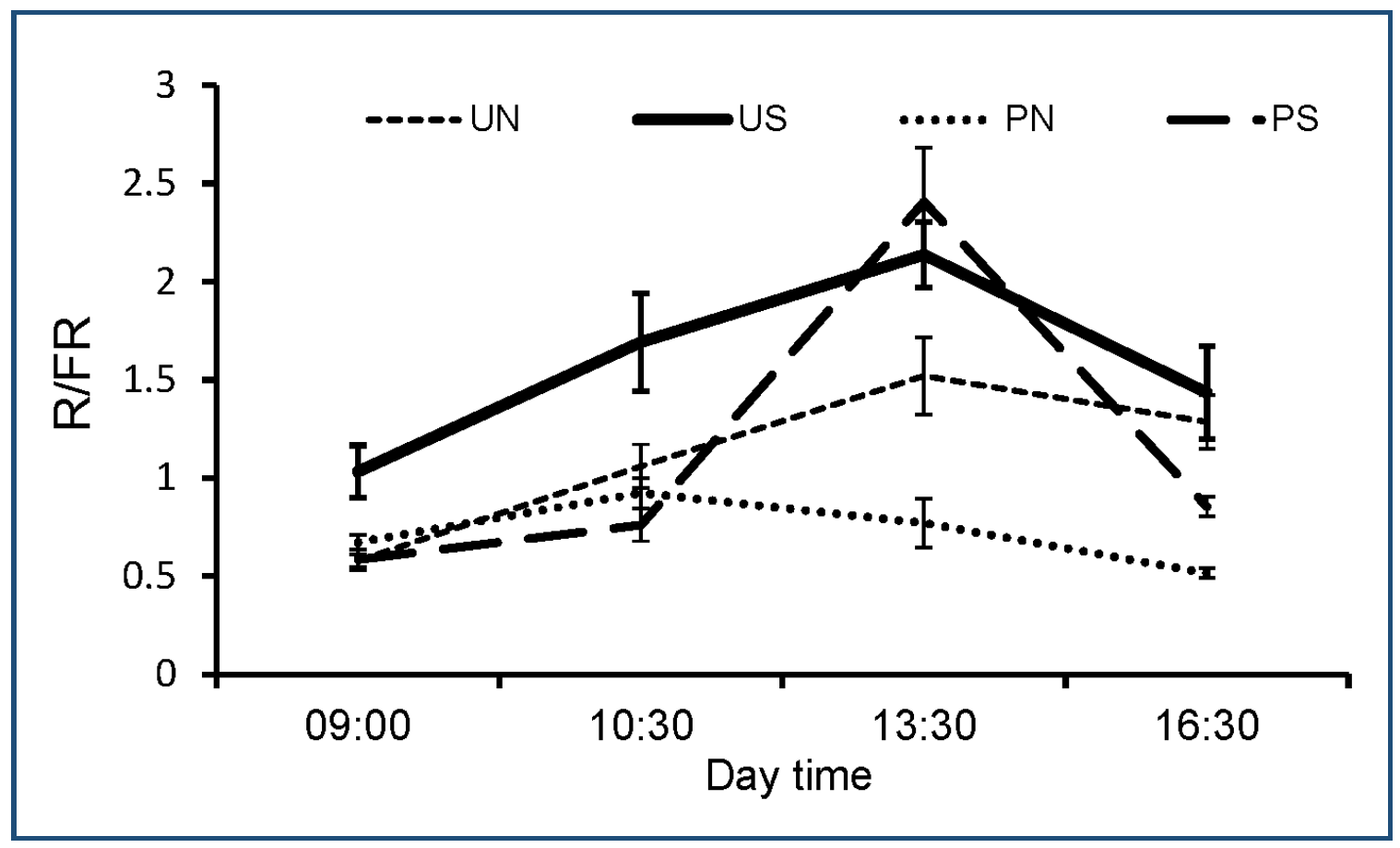

Fig. 1. Mean \pm Standard Error values of R/FR ratios at four microsite types in the Abies religiosa forest in the Magdalena river basin:US (undisturbed -non weeded-, south oriented), PS (perturbed -weeded-, south oriented), UN (undisturbed -non weeded-, north oriented), PN (perturbed -weeded-, north oriented), SE bars are shown. 


\section{Soil temperature and moisture at microsites}

All microsites differed in their soil temperature and moisture mean values. PS exhibited the highest temperature $\left(\overline{\mathrm{X}}=12.2 \pm\right.$ S.E. $\left.=0.03^{\circ} \mathrm{C}\right)$ and the lowest soil moisture value $(\overline{\mathrm{X}}=57.5 \pm$ S.E. $=0.15 \%)$. The UN microsites had the lowest mean temperature $\left(\bar{X}=9.9 \pm\right.$ S.E. $\left.=0.04^{\circ} \mathrm{C}\right)$ and the highest mean value for soil moisture $(\bar{X}=68 \pm$ S.E. $=0.17 \%)$, (table 1$)$. The effects of the variables of temperature and moisture at $\mathrm{PN}$ and UN microsites, were significant for the germination of $S$. angulifolius, while at UN moisture had a significant effect on the germination of A. glabrata (table 2).

\section{Germination responses to different light qualities in growth chambers}

Ageratina glabrata showed the highest percentages of germination under white light (WL), while S. angulifolius showed the highest percentages under far-red light (FRL) (table 3). Viability percentages decreased from 85\% to $75 \%$ from 2016 to 2017 for A. glabrata and from $80 \%$ to $75 \%$ for $S$. angulifolius.

Table 3. Mean values \pm Standard Error of germination percentages, lag time and germination rate of the two shrub species from the Abies religiosa forest in Magdalena river basin, under different light qualities in germination chambers. WL (White light), RL (Red light), FRL (Far red light), D (Darkness). Values of Lag time (Days),

Germination rate and viability percentages are included for 2016 and 2017.

\begin{tabular}{ccc}
\hline Species/light quality & Ageratina glabrata & Senecio angulifolius \\
\hline WL & $58.7 \pm 1.2$ & $\mathbf{2 7 . 3} \pm \mathbf{3 . 6}$ \\
RL & $\mathbf{2 4 . 8} \pm \mathbf{1 . 3}$ & $\mathbf{1 0 . 1} \pm \mathbf{1 . 3}$ \\
FRL & $\mathbf{3 2 . 7} \pm \mathbf{3 . 2}$ & $39.7 \pm 3.7$ \\
D & $\mathbf{3 8 . 7} \pm \mathbf{1 . 8}$ & $\mathbf{1 9 . 4} \pm \mathbf{1 . 6}$ \\
\hline Lag time & $\mathbf{3 . 5} \pm \mathbf{0 . 4 6}$ & $\mathbf{4 . 0 1} \pm \mathbf{0 . 1 5}$ \\
Germination rate & $\mathbf{6 . 8} \pm \mathbf{0 . 8 1}$ & $\mathbf{5 . 3 1} \pm \mathbf{3 . 0 7}$ \\
Viability (\%) 2016 (a) and 2017 (b) & (a) $85,(\mathbf{b}) \mathbf{7 5}$ & (a)80, (b)75 \\
\hline
\end{tabular}

\section{DISCUSSION}

The environment surrounding seeds in the soil partially determines seed fate. According to some authors, in small seed species ( $\sim 3 \mathrm{~mm}$ long, such as the studied species), a microsite may be no more than a few centimeters in diameter (Fowler, 1988). Microsites do not form a continuum in a forest, and differences in micro environmental variables will arise due to forest complexity at different scales, which can occur naturally but also, they can be influenced by some silvicultural practices and disturbances (Caviedes and Ibarra, 2017; Martínez-Orea et al., 2019).

Light in microsites is a signal for seed germination and is a highly variable environmental factor (Messier and Puttonen, 1995). At the soil level, light in microsites can be modulated by three factors: canopy gap size, slope orientation (Ritter et al., 2005), and by the presence/absence of secondary vegetation as observed in this study. Despite its removal by silvicultural practices, $\mathrm{P}$ microsites exhibited the smallest values of the GSF and R/FR ratio; therefore, weeding did not increase their values. This is related to the fact that gaps were larger at $\mathrm{U}$ than at $\mathrm{P}$ microsites, which was measured not only through the GSF, but through the visible sky fraction value ( $\mathrm{U} \square=0.21>\mathrm{P} \square=0.088$ ), and also because in the former, the trees grow separately due to previous selective tree cutting due to management plans and also due to illegal deforestation (Cantoral et al., 2009). It was evident that S microsites were the highest in light. This concurs broadly with Stuart et al. (1988) and Ackerly et al. (2002) who also reported higher values of diurnal insolation at $\mathrm{S}$ than at $\mathrm{N}$ sites in a Californian chaparral, as occurs in 
the Northern Hemisphere. For a tropical dry forest in Mexico, Méndez-Toribio et al. (2016) also reported higher light levels (16\% more) in slopes south-facing. As R/FR ratio values were the smallest at PN microsites, the amount of FR light there was higher; despite these differences, R/FR ratios did not have statistical effects for any species. However, GSF did show significant effects for A. glabrata meaning that as most secondary species, it is highly responsive to gap openings (Redwood et al., 2016), where all types of light are present, besides in UN microsites the intermediate values of FSG are significantly related to intermediate values of germination of this species.

In terms of the light requirements for the germination of both species, S. angulifolius showed the highest germination percentages in FR light conditions in growth chambers. Other shrub species in this study area have been reported to germinate in high percentages in FR light as well (Martínez-Camacho et al., 2018; Martínez-Orea et al., 2019). In field conditions, germination was the highest for both species at US microsites, where RL values were higher than FRL. This result was related to the fact that conditions in nature are obviously more heterogeneous than those in controlled environments and the R/FR ratios vary not only along day as our results pointed out, but also depending on the gap size and the understory species composition (Vázquez-Yanes et al., 1990; Pearson et al., 2003). We assume that there was a broader gradient in the intensity and in the spectral quality of the light at US microsites caused by the higher heterogeneity in foliage (provided by the secondary vegetation species), litter and on the soil surface where seeds were. This photoblastic response is observed particularly in small seeds (Jankowska and Daws, 2007), such as the seeds of our study species, in the order of 0.032-0.23 mg, fresh weight (Millberg et al., 2000).

There is a wide variety of R/FR values among forests and under different gap sizes. For example, according to Endler (1993), R/FR values close to 1.15 correspond to small gaps in temperate forests of North America and are similar to those in our study, specifically at the $\mathrm{P}$ microsites. According to Martínez-Camacho (2015) and Endler (1993) R/FR values between $0.99-1.13$ correspond to small gaps. According to Pearson et al. (2003), large gaps are between 1.18 and 1.5, and small gaps are around 0.92. Based on these authors, all our microsites correspond to large gaps, which is understandable if we consider that this is a forest constantly affected by anthropogenic disturbances mainly illegal and sometimes planned wood harvesting (Ávila-Akerberg et al., 2018). It is interesting to note that the maximum of RL peak was reached in PS microsites close to midday. This result might be due to the absence of herbs and shrubs; therefore, light is only filtered by the canopy.

For light availability at the soil level, canopy gaps and slope orientation are the main factors, but for light quality, the absence of understory vegetation may play an important role because it filters light and may buffer drastic light changes (Vázquez-Yanes et al., 1990). Our results are consistent with those of Messier and Puttonen (1995), who found significant effects of understory species on light dynamics at the soil level. Nevertheless, it is difficult to understand the threshold of the R/FR ratio values required for maximum germination in field conditions (Pearson et al., 2003).

Another environmental variable that affects germination is temperature. According to Pearson et al. (2003), fluctuations in temperature of 1 to $2^{\circ} \mathrm{C}$, such as those observed at our US microsites, can act together with low R/FR ratios to stimulate germination. Therefore, the highest germination percentages of both species at US can be explained because it was at these microsites, where variations in mean temperature were observed (the second lowest and the highest mean temperatures) during the study month, intermediate mean temperatures. Finch and Leubner (2006) mention that seeds of some species can turn their sensitivity to a determined light quality depending on temperature. If we also consider that US microsites were the highest in soil moisture (required for seed imbibition), the mentioned conditions of light, moisture and temperature must have been related with the highest percentages of germination for both species at US. 
Forest gaps, slope orientation and silvicultural practices have a strong effect on microsite soil temperature and moisture. Microsites north-facing receive less input of solar energy than southfacing ones, which is why they are generally cooler and moister (Martínez-Orea et al., 2019) in the northern hemisphere, were the study forest is located. This result has also been reported before by Méndez-Toribio et al. (2016) who found that south-facing sites are $2^{\circ} \mathrm{C}$ warmer than north-facing sites in a seasonally dry forest in Mexico, and by Haase (1970) and Chen et al. (1999), who reported higher temperatures and lower values for soil moisture on south-facing slopes in the mountains of Arizona.

In our study, the differences in these variables were also associated with disturbance because the PS microsites were the highest in temperature and the lowest in soil moisture, while UN were the highest in soil moisture and the lowest in soil temperature. In general north-facing microsites showed smaller values of temperature $\left(1.08^{\circ} \mathrm{C}\right.$ less than $\mathrm{S}$ microsites $)$ and higher values of moisture (4\% more humid than $\mathrm{S}$ microsites), and this was significantly related to seed germination, for the case of $S$. angulifolius this was particularly important because lowest values of soil temperature and the highest of moisture seem to have negatively affected its germination, which occurred at UN microsites. Luna-Bautista et al. (2015) indicate that logging modifies richness, diversity and composition of the tree strata (shrub and herbaceous) and since understory is the largest contributor to diversity it is important to assess it, because it helps giving a better explanation of the total plant diversity of the forest ecosystem.

Our study site has been reported as highly variable in terms of soil moisture conditions, exhibiting $15 \%$ more soil moisture at sites under small gaps than at sites under larger gaps (Bonilla-Valencia et al., 2017a, 2017b). There was 9\% more soil moisture under larger gaps, corresponding to the $\mathrm{U}$ microsites, because secondary vegetation exerts a protective effect against the loss of humidity (Chaneton et al., 2010). It seems that this disturbance together with slope orientation has stronger effects on soil moisture and temperature than the size of canopy gaps as has been observed by other studies in this site (Martínez-Orea et al., 2019).

After weeding, an increase in the availability of some nutrients in the soil may occur. Nitrogen (Ni) contents can increase, and lower values of $\mathrm{pH}$ can be observed after a sudden deposition of plant material (Raulund-Rasmussen et al., 2008), especially at humid microsites (Brown et al., 1996). Our results showed these patterns slightly, as the highest $\mathrm{Ni}$ was registered at PS microsites, but the $\mathrm{pH}$ values and germination percentages of both species were intermediate. Low values of $\mathrm{pH}$ and high values of $\mathrm{Ni}$ (in the form of nitrites and nitrates) have been reported to lixiviate seed coats and cause seed germination in some species (Pons, 2000). This has been observed in annual species in a Californian chaparral (Keeley and Fotheringham, 1997), as well as in some weeds (Peishi et al. 1999). Nevertheless, $\mathrm{pH}$ values were the lowest at PN microsites, but $\mathrm{Ni}$ values were intermediate, with intermediate germination values for $S$. angulifolius and the smallest for A. glabrata. Germination seemed to respond to the variation of these variables and not necessarily to their highest or lowest values according to the GLM. For some species, Bell et al. (1999) reported inhibition of germination by high concentrations of soil nitrates on Oenothera stricta (Onagraceae), while for some Asteraceae such as Leucochrysum fitzgibbonii and Crasipedia sp nitrates influenced germination positively in Western Australia. The highest values of germination for both species occurred at US microsites, where high values of $\mathrm{pH}$ and intermediate of $\mathrm{Ni}$ were found and it was in US microsites where $\mathrm{pH}$ and $\mathrm{Ni}$ had significant effects on $S$. angulifolius germination. It is important to consider that more than one variable has an effect on germination; it is the result of several variables and their interaction at microsites.

The clearest trend in our data indicates that since the study species are secondary, their germination is highly determined by light availability, high soil moisture and temperature variations (Baskin and Baskin, 1998; Milberg et al., 2000) due to gap size, slope orientation, and the availability of secondary vegetation as seen in other shrubs of temperate forests 
(Martínez-Orea et al., 2019). And the effect of this silvicultural practice on soil $\mathrm{pH}$ and $\mathrm{Ni}$ and how these variables affect seed germination needs further research.

The germination percentages of both species in the microsites were under $20 \%$. The temperatures at the time of the experiment were in the range of $9.99-12.4^{\circ} \mathrm{C}$, and both species have been shown to reach $80-100 \%$ of germination under $20-25^{\circ} \mathrm{C}$ (Walck et al., 1997; Royal Botanic Gardens Kew, 2019). Although seeds were sown when mature and right after collection and during dispersal times, the best temperatures for germination are most likely reached in June, when temperatures of $20-25^{\circ} \mathrm{C}$ have been recorded (Vázquez-Santos et al., 2019 in press) at this study site and when soil moisture values reach $100 \%$, during the onset of the rainy season, therefore seed germination can vary between seasons independently from seed maturity (Baskin and Baskin, 1998). Although seeds of many species will germinate at constant temperatures, the germination of many shrub species increases due to temperature fluctuations (Zambino, 2010; Martínez-Orea et al., 2019). Another factor that could explain the low germination percentages registered could be the presence of primary seed dormancy. These species are orthodox (Royal Botanic Gardens Kew, 2019), so their seeds can be stored in a soil seed bank, this is why it is important to maintain organic matter on the forest floor (Mackenzie and Naeth, 2010). These seeds may remain viable for some time on the forest soil, according to Radford and Cousens (2000). Although rapid germination (in the first 15 days after sowing) has been registered for some Senecio species (as in our study), some are known to remain viable in the soil for up to eight years, especially in disturbed habitats with good light availability. Perhaps approximately $20 \%$ of our seeds were quiescent because they germinated in two weeks after sowing, and the remainder was most likely dormant. Kadereit (1984) and Ren and Abbott (1991) found that some Senecio species produce a greater proportion of seeds that are dormant, although at least $30 \%$ of them can germinate within 28 days after sowing.

\section{CONCLUSIONS}

Based on our results we do not recommend weeding and consider this silvicultural practice as a disturbance because it can negatively affect the availability of safe microsites for the germination of some shrubs, like the study species. This practice should not be carried out especially in south-facing slopes, because they are naturally warmer and less humid than northfacing slopes and after weeding a loss of soil moisture and an increase in temperature can arise. We recommend a planning on weeding, and if it is done, it should not be frequent in sites where it has already been practiced. Although the germination percentages were low at all microsites, the loss of soil moisture can be a post disturbance variable that might risk the germination of these species. A. glabrata germination in north-facing microsites seemed to be affected negatively by this disturbance, which was probably related to the lowest $\mathrm{pH}$ values registered there. S. angulifolius germination seemed to be less successful in north-facing microsites; however, if weeding is implemented frequently, then the changes in the microsite might affect germination negatively. More studies regarding microsite suitability for secondary species germination are required in terms of specific disturbances, since environmental variables can respond uniquely to particular forest management, and so may biological processes, such as germination. The seeds of these species can be stored for at least one year because they can maintain their viability in good percentages.

\section{ACKNOWLEDGEMENTS}

Special thanks to M. in Sc. Ma. Esther Sánchez-Coronado and M. in Sc. Beatríz Zúñiga-Ruíz for their assistance in germination tests. We acknowledge Biol. Marco A. Romero-Romero for figure edition. To Posgrado en Ciencias Biológicas, UNAM. 


\section{LITERATURE CITED}

Ackerly, D., S. Knight, P. Weiss, P. Barton \& K. Starmer. (2002). Leaf size, specific leaf area and microhabitat distribution of chaparral woody plants: contrasting patterns in species level and community level analyses. Oecologia, 130(3), 449-457. DOI $10.1007 / \mathrm{s} 004420100805$

Álvarez-Román, K.E. (2000). Geografía de la educación ambiental: algunas propuestas de trabajo en el bosque de los Dinamos, área de conservación ecológica de la Delegación Magdalena Contreras. Tesis de Licenciatura. Facultad de Filosofía y Letras, Universidad Nacional Autónoma de México.

Ávila-Akerberg V., M. Nava-López, V. Aguilar-Zamora y L. Almeida-Leñero. (2018). La Vegetación boscosa y el uso del suelo de la cuenca del río Magdalena. En: Historia natural y cultural de la cuenca del río Magdalena. Almeida-Leñero L., J. Carmona Jiménez, E.A. Cantoral-Uriza Eds. Universidad Nacional Autónoma de México. 452 p.

Ávila-Akerberg, V. (2002). La vegetación en la cuenca alta del río Magdalena: Un enfoque florístico, fitosociológico y estructural. México. Tesis de Licenciatura. Facultad de Ciencias, Universidad Nacional Autónoma de México.

Baskin, C., \& J. Baskin. (1998). Germination Ecophysiology of Herbaceous Plant Species in a Temperate Region. Am J Bot, 75(2), 286-305.

Bell, D.T., L.A. King, \& J.A. Plummer. (1999). Ecophysiological effects of light quality and nitrate on seed germination in species from Western Australia. Aust J Ecol, 24(1), 210. https://doi.org/10.1046/j.1442-9993.1999.00940.x

Benvenuti, S. \& M. Mazzoncini. (2019). Soil Physics Involvement in the Germination Ecology of Buried Weed Seeds. Plants, 8(7). doi:10.3390/plants8010007

Bonilla-Valencia, L., S. Castillo-Argüero, \& Y. Martínez-Orea. (2017a). Reproductive phenology of Sambucus nigra subsp. canadensis (L.) Bolli in the Abies religiosa temperate forest of the Magdalena river basin, Mexico City. Bot Sci, 95(1), 1-13. DOI: $10.17129 /$ botsci.626

Bonilla-Valencia, L., Y. Martínez-Orea, S. Castillo-Argüero, G. Barajas-Guzmán, M.A. Romero-Romero, \& E. Díaz-López. (2017b). Reproductive phenology of understory species in an Abies religiosa (Pinaceae) forest in the Magdalena River Basin, Mexico City. J Torrey Bot Soc, 144(3), 313-327. https://doi.org/10.3159/TORREY-D-1600024.1

Brown, S., J. Mo, J. McPherson, \& D. Bell. (1996). Decomposition of woody debris in Western Australian forests. Can J Forest Res, 26(6), 954-966. DOI: 10.1139/x26-105

Cabrera-Rodríguez, L. y J.L. Villaseñor. (1987). Revisión bibliográfica sobre el conocimiento de la familia Compositae en México. Biótica, 12, 131-147.

Calderón, G., y J. Rzedowski. (2005). Flora fanerogámica del Valle de México. México. Instituto de Ecología A.C. (INECOL) y Comisión Nacional para el Conocimiento y Uso de la Biodiversidad (CONABIO). $1406 \mathrm{p}$.

Canham, D., J. Denslow, W. Platt, J. Runkle, T. Spies, \& P. White. (1990). Light regimes beneath closed canopies and tree-fall gaps in temperate and tropical forests. Can $J$ Forest Res, 20(5), 620-631. https://doi.org/10.1139/x90-084

Cantoral, E., L. Almeida, J. Cifuentes, L. León, A. Martínez, y Nieto, A. (2009). La biodiversidad de una cuenca en la ciudad de México. Ciencias, 94(094).

Castro, J., R. Zamora, J. Hódar, \& J. Gómez. (2002). Use of Shrubs as Nurse Plants: a new technique for reforestation in mediterranean mountains. Restor Ecol, 10(2), 297-305. https://doi.org/10.1046/j.1526-100X.2002.01022.x

Caviedes, J., \& J.T. Ibarra. (2017). Influence of anthropogenic disturbances on stand structural complexity in Andean temperate forests: implications for managing key habitat for biodiversity. PloS one, 12(1), e0169450.

Chaneton, E., N. Mazía, \& T. Kitzberger. (2010). Facilitation vs apparent competition: insect herbivory alters tree seedling recruitment under nurse shrubs in a steppe-woodland ecotone. J Ecol, 98(2), 488-497. doi: 10.1111/j.1365-2745.2009.01631.x 
Chen, J., S. Saunders, T. Crow, R. Naiman, K. Brosofske, G. Mroz, B. Brookshire, \& J. Franklin. (1999). Microclimate in Forest Ecosystem and Landscape Ecology Variations in local climate can be used to monitor and compare the effects of different management regimes. BioScience, 49(4), 288-297. https://doi.org/10.2307/1313612

Crawley, M. J. (2012). The R book. John Wiley \& Sons. West Sussex, UK. 939 pp.

Dobler-Morales, C.E. (2010). Caracterización del clima y su relación con la distribución de la vegetación en el suroeste del D.F., México. Tesis de Licenciatura. Facultad de Ciencias, Universidad Nacional Autónoma de México.

Endler, J.A. (1993). The color of light in forests and its implications. Ecol Monogr, 63(1), 1-27. https://doi.org/10.2307/2937121

Evans, R.A., \& J.A. Young. (1984). Microsite requirements for downy brome (Bromus tectorum) infestation and control on sagebrush rangelands. Weed Science, 32(S1), 1317.

Finch-Savage, W.E., \& G. Leubner-Metzger. (2006). Seed dormancy and the control of germination. New phytologist, 171(3), 501-523.

Fowler, N. (1988). What is a Safe Site?: Neighbor, Litter, Germination Date, and Patch Effects. Ecology, 69(4), 947-961.

García, E. (2004). Modificaciones al Sistema de Clasificación Climática de Köppen para Adaptarlo a las Condiciones de la República Mexicana, 6th ed. Instituto de Geografía, UNAM, Ciudad de México. 90 p.

González, J.M., A.Z. Lupercio y H.D. López. (2013). Dasonomía Urbana. Ingeniería Forestal. Memoria de Prácticas Silvícolas. Universidad Autónoma de Chapingo. 314p.

Haase, E.F. (1970). Environmental Fluctuations on South-Facing Slopes in the Santa Catalina Mountains of Arizona. Ecology, 51(6), 959-974. https://doi.org/10.2307/1933623

Jankowska-Blaszczuk, M., \& M.I. Daws. (2007). Impact of red: far red ratios on germination of temperate forest herbs in relation to shade tolerance, seed mass and persistence in the soil. Functional Ecology, 21(6), 1055-1062. https://doi.org/10.1111/j.13652435.2007.01328.x

Kadereit, J. (1984). Studies on the biology of Senecio vulgaris L. ssp. denticulatus (O. F. Muell). P. D. Sell. New Phytol, 97(4), 681-689. https://doi.org/10.1111/j.14698137.1984.tb03631.x

Keeley, J.E., \& C. Fotheringham. (1997). Trace gas emissions and smoke-induced seed germination. Science, 276(5316), 1248-1250. DOI: 10.1126/science.276.5316.1248

Lindig-Cisneros, R., \& Zedler, J. B. (2002). Relationships between canopy complexity and germination microsites for Phalaris arundinacea L. Oecologia, 133(2), 159-167.

Luna-Bautista, L., P. Hernández-de la Rosa, A. Velázquez-Martínez, A. Gómez-Guerrero, y M. Acosta-Mireles. (2015). Understory in the composition and diversity of managed forest areas in Santa Catarina Ixtepeji, Oaxaca. Revista Chapingo. Serie Ciencias Forestales y del Ambiente, 21(1).

Mackenzie, D.D., \& M.A. Naeth. (2010). The role of the forest soil propagule bank in assisted natural recovery after oil sands mining. Restor Ecol, 18(4), 418-427.

Marschner, I.C. (2015). Relative risk regression for binary outcomes: Methods and recommendations. Aust N Z J Stat, 57(4), 437-462.

Martínez-Camacho, Y.D. (2015). Ecofisiología de la germinación de Acaena elongata del bosque de Abies religiosa de la cuenca del río Magdalena, México D.F. Tesis de Licenciatura. Facultad de Ciencias, Universidad Nacional Autónoma de México.

Martínez-Camacho, Y. D., S. Castillo-Argüero, Y. Martínez-Orea, y M.E. Sánchez-Coronado. (2018). Ecofisiología de la germinación de Acaena elongata (Rosaceae), una especie indicadora de perturbación de un bosque templado, al sur de la Ciudad de México. REV MEX BIODIVERS, 89(3), 806-814.

Martínez-Orea, Y., A. Orozco-Segovia, S. Castillo-Argüero, M. Collazo-Ortega, \& J.A. ZavalaHurtado. (2014). Seed rain as a source of propagules for natural regeneration in a temperate forest in Mexico City. J Torrey Bot Soc, 141(2), 135-150. https://doi.org/10.3159/TORREY-D-13-00032.1 
Martínez-Orea, Y., S. Castillo-Argüero, A. Orozco-Segovia, A. Zavala-Hurtado, J. A., y L. Bonilla-Valencia. (2019). Micrositios seguros para la germinación de Symphoricarpos microphyllus (Caprifoliaceae), una especie arbustiva con latencia. ACTA BOT MEX, (126), 1-15. https://doi.org/10.21829/abm126.2019.1458

Matlack, G. (1993). Microenvironment variation within and among forest edge sites in the Eastern United States. Biol Conserv, 66(3), 185-194. https://doi.org/10.1016/00063207(93)90004-K

Méndez-Toribio, M., J.A. Meave, I. Zermeño-Hernández and G. Ibarra-Manríquez. (2016). Effects of slope aspect and topographic position on environmental variables, disturbance regime and tree community attributes in a seasonal tropical dry forest. Journal of Vegetation Science 27(6), 1094-1103. DOI: https://doi.org/10.1111/jvs.12455.

Messier, C., \& P. Puttonen. (1995). Spatial and temporal variations in the light environment of developing Scots pine stands: the basis for a quick and efficient method of characterizing light. Can J Forest Rest, 25(2), 343-354. https://doi.org/10.1139/X95038

Milberg, P., L. Anderson, \& K. Thompson. (2000). Large-seeded species are less dependent on light for germination than small-seeded ones. Seed Sci Res, 10(1), 99-104.

Moreno-Martínez, E. (1996). Análisis físico y biológico de semillas agrícolas. 3a. Edición. Universidad Nacional Autónoma de México. 313 p.

Orozco-Segovia, A., y M.E. Sánchez-Coronado (2013). Germinación. In: Biología de angiospermas. Eds. Márquez-Guzmán J, M. Collazo-Ortega, M. Martínez-Gordillo, A. Orozco-Segovia, S. Vázquez-Santana. Universidad Nacional Autónoma de México. Las prensas de Ciencias.

Pearson, T.R., D.F. Burslem, C.E. Mullins, \& J.W. Dalling. (2003). Functional significance of photoblastic germination in neotropical pioneer trees: a seed's eye view. Funct Ecol, 17(3), 394-402. https://doi.org/10.1046/j.1365-2435.2003.00747.x

Peishi, Z., J. Plummer, D. Bell, D. Turner, \& D. Choengsaat. (1999). Low-and hightemperature storage effects on viability and germinability of seeds of three Australian Asteraceae. Aust J Bot, 47(2), 265-275. https://doi.org/10.1071/BT97105

Pons, T. (2000). Seed Responses to light. In Seeds: The Ecology of Regeneration in Plant Communities. 2nd edition. 385 p.

R Core Team. 2015. R: A Language and Environment for Statistical Computing. R Foundation for Statistical Computing. Vienna, Austria.

Radford, I., \& R. Cousens. (2000). Invasiveness and Comparative Life-History Traits of Exotic and Indigenous Senecio Species in Australia. Oecologia, 125(4), 531-542. https://doi.org/10.1007/s004420000474

Raulund-Rasmussen, K., I. Stupak, N. Clarke, I. Callesen, H. Helmisaari, E. Karltun, \& I. Varnagiryte-Kabasinskiene. (2008). Effects of very intensive forest biomass harvesting on short and long term site productivity. In: D. Röser et al. Eds. (2008). Sustainable Use of Forest Biomass for Energy: A Synthesis with Focus on the Baltic and Nordic Region, 29-78 pp. Springer Science and Business Media B.V.

Redwood, M.E., G.R. Matlack \& C.D. Huebner. (2016). Seed longevity and dormancy state in a disturbance-dependent forest herb, Ageratina altissima. Seed Sci Res, 26(2), 148-152. https://doi.org/10.1017/S0960258516000052

Ren, Z., \& R. Abbott. (1991). Seed dormancy in Mediterranean Senecio vulgaris L. New Phytol, 117(4), 673-678. https://doi.org/10.1111/j.1469-8137.1991.tb00972.x

Ritter, E., L. Dalsgaard, \& K. Einhorn. (2005). Light, temperature and soil moisture regimes following gap formation in a semi-natural beech-dominated forest in Denmark. For Ecol Manage, 206(1-3), 15-33. https://doi.org/10.1016/j.foreco.2004.08.011

Rodríguez-Trejo, D. (2006). Notas sobre el diseño de plantaciones de restauración. Revista Chapingo Serie Ciencias Forestales y del Ambiente, 12(2), 111-123.

Royal Botanic Gardens Kew. (2019) Seed Information Database (SID). Version 7.1. Available from: http://data.kew.org/sid/ (June 2019). 
Recibido:

14/marzo/2019

Aceptado:

28/junio/2019
Santibáñez-Andrade, G., S. Castillo-Argüero, y Y. Martínez-Orea. (2015). Evaluación del estado de conservación de la vegetación de los bosques de una cuenca heterogénea del Valle de México. BOSQUE, 36(2), 299-313. http://dx.doi.org/10.4067/S071792002015000200015

Stat Soft. 2007. STATISTICA, data analysis software System, version 8.0. Tulsa, USA.

Stuart, W., D. Murphy \& R. Raymond. (1988). Sun, Slope, and Butterflies: Topographic Determinants of Habitat Quality for Euphydryas edita. Ecology, 69(5), 1486-1496. https://doi.org/10.2307/1941646

Vázquez-Santos Y., S. Castillo-Argüero, Y. Martínez-Orea, I. Sánchez-Gallén, R. Vega-Frutis, S.L. Camargo-Ricalde, L.V. Hernández-Cuevas. (2019). The reproductive phenology of Acaena elongata and its relation with arbuscular mycorrhizal fungi. Symbiosis. In press.

Vázquez-Yanes, C., A. Orozco-Segovia, E.A. Rincón, M.E. Sanchez-Coronado, P. Huante, J. Toledo, \& V.L. Barradas. (1990). Light beneath the litter in a tropical forest: effect on seed germination. Ecology, 71(5), 1952-1958. https://doi.org/10.2307/1937603

Villaseñor, J.L. (2003). Diversidad y distribución de las Magnoliophyta de México. Interciencia, 28(3), 160-167.

Walck, J., C. Baskin \& J. Baskin. (1997). Comparative Achene Germination Requirements of the Rockhouse Endemic Ageratina luciae-brauniae and its Widespread Close Relative A. altissima (Asteraceae). Am Midl Nat, 137(1), 1-12.

Zambino, P.J. (2010). Biology and pathology of Ribes and their implications for management of white pine blister rust. Forest Pathology, 40(3-4), 264-291.

Zar, J.H. (1999). Biostatistical Analysis. Prentice Hall. Englewood Cliffs, NJ, EEUU. 620 p.

Zuloaga-Aguilar, S., Briones, O., \& Orozco-Segovia, A. (2011). Seed germination of montane forest species in response to ash, smoke and heat shock in Mexico. Acta Oecologica, 37(3), 256-262. 